\title{
An Analysis of Female Consciousness in Uncle Tom's Cabin
}

\author{
Yang Zhao \\ Foreign Languages College, Beihua University, Jilin 132013, China
}

Keywords: Mrs. Stowe, Uncle Tom’s Cabin, Female Consciousness, Inequality.

\begin{abstract}
Uncle Tom's Cabin is an anti-slavery novel by Harriet Beecher Stowe. It was published in 1852. This novel mainly tells a story about the miserable life of black slaves and their efforts fighting for freedom. It exposes and accuses the evil of slavery. By emphasizing the moral strength of women and describing maternal love in an idealized way, the author tries to awaken the sympathy of American women and appeals them to oppose slavery and save the society. The unique literary creation of the novel and analysis of the tragic life of the black women have laid the irreplaceable position of Uncle Tom's Cabin in the literary world. This thesis attempts to elaborate the female consciousness in Uncle Tom's Cabin and its influence on the society at that time by analyzing the main female characters in the novel and combining with the social background of the United States.
\end{abstract}

\section{Introduction}

Uncle Tom's Cabin which was published in 1852 is an anti-slavery novel. By depicting a series of appalling pictures, it revealed the brutal face of the slavery and exposed the sins of the southern slave owners. Meanwhile, it aroused great resentment of the northern people and played an important role in promoting the Abolition Movement. Besides, it was considered to have directly triggered the Civil War. The novel was set in the history of the eve of the American Civil War in the mid- $19^{\text {th }}$ century. It mainly tells a story about the African American slaves, which focused the tragic fate of the black slave Tom. Its layout is unique with two lines telling the bitter history of the black people. On one hand, the novel created Tom who was faithful and friendly but submissive, on the other hand, it praised Eliza for her courage of fighting for freedom. Through depicting the characters and scenes, it revealed the American social life of that period so as to advocate the Christianity idea "return good for evil."

\section{Female Characters}

Eliza is a second-generation quadroon, with a charming face, beautiful voice and graceful manners. Before learning her son was to be sold, she was obedient, gentle and timid, and devoted all her maternal love to her son, Harry. When she overheard the master talking about selling Harry to a brutal slave trader, Haley, she turned deathly pale and shivered with rigid features and compressed lips. Which mother could bear the misery of being separated from her children forever with nothing to do? Maternal love was beyond her loyalty to the master, so she carried Harry and fled overnight. Eliza's escape shows this vulnerable group's courage of independence, and faith of self-liberation, which has changed people's prejudice against black women. Instead of being the silence of lamb, they have become courageous and prudent.

Aunt Chloe is Uncle Tom's wife. She knew deeply that the southern slavery regulations are severer than the northern. In order to hide her internal worry and anxiety about the fate of herself and her family, she pretended to be a simple and silly cook in front of the Shelby. She was grateful to the mistress for giving her everything but when Aunt Chloe knew that Mr. Shelby wanted to sell Tom to pay off his debt, she bravely expressed her resentment to the master and acted decisively to support her husband to flee. The hatred of slavery and the disappointment of the master's treachery 
accelerated the self-awakening of Aunt Chloe. Instead of depending to the master to save Tom, she decided to rely on her own efforts by making cakes to earn extra income. It was a drop in the bucket, but she never changed her mind to save her husband.

Topsy was a black girl, about eight or nine years old. "She was one of the blackest of her race; and her round, shining eyes, glittering as glass beads, moved with quick and restless glances over everything in the room." "She was dressed in a single filthy, ragged garment, made of bagging; and stood with her hands demurely folded before her." She was raised by a speculator and didn't have parents, brothers and sisters. Before coming to Eva's home, her world was only full of insults and beatings, lies and theft. She even regarded her fault and evil behavior as a show-off, and mistakenly assumed that these things were special honors. After arriving at Eva's home, she was treated with kindness. Every time she was scolded, Eva would help her get out of trouble which just like a ray of sunshine shining in her dark inner world. Topsy was a gift that Mr. St Clair bought for Miss Ophelia. She was a disobedient and wicked child, who still persisted in her old ways even when she was beaten black and blue. She was chosen by Mr. St. Clare because of his doubt about Ophelia's educational philosophy and curiosity about what the nigger would be like after having received a good orthodox New England education. In addition, Mr. St. Clare did not believe that Miss Ophelia would really love such a little girl. Obviously, he completely underestimated Topsy and Ophelia. In the end, Topsy was changed by Eva's love and achieved herself under Miss Ophelia's earnest teaching. To some extent, Topsy's change was a powerful attack on the men who underestimated the women's capability.

Eva was a white girl, who grew up in a wealthy family with both parents loving her, especially her father. Her whole heart and soul were absorbed in works of love and kindness. For instance, in order to make Uncle Tom happy, she asked her father to buy him from the hands of the slave trader; out of sympathy for slaves, she hoped that her father could give freedom to all the slaves. Meanwhile, Eva's strong belief in saving the world not only made her father decide to release the slaves, but also influenced Topsy and Ophelia. Eva was friendly to the slaves. She not only read the Bible to them but also tried every possible way to teach them to read. She always spared no effort to use Christian spirit to influence them, to educate them, to let them know what love was and how to love others. By shaping the image of Eva, Mrs. Stowe shows the spirit of Christianity and the spirit of love that she advocated.

\section{Female Consciousness}

In this novel, the little black slave Topsy not playing by the rules was a typical representative of the feminist resistance. In the male-dominated society, the traditional family division defined women as obedient and humble. It is unnecessary for them to receive too much education because the most important thing they need to do was to be adept at doing housework and needlework. On the contrary, Topsy was smart and energetic in all manual operations, learning everything that was taught her with surprising quickness, but she hated to do needlework and broke her needles, throwing them slyly out of windows. When she was happy, she would clean up the room in accordance with Miss Ophelia's order, but things would be messed up in a moment.

Mrs. Stowe appealed women to get rid of their traditional role in the male-dominated society and bravely pursued self-liberation.

Mrs. Shelby was another rebellious character in this novel. She had made a clear statement against her husband's decision of selling Tom and Harry, though she failed to rescue Tom and Harry because of her limitations, at least she didn't stand by. When she heard of Eliza's escaping, she was glad and tried to drag the slave trader Haley to win more escaping time for Eliza. After Tom was sold, her husband's business was still bad, but Mrs. Shelby never forgot her promise to buy Tom back. She once offered to help her husband manage his business and was rejected by her husband on grounds of her ignorance. When she proposed to take music-scholars to earn money, her husband stopped her again because she would degrade herself if she did so. Despite she seldom succeeded, Mrs. Shelby never succumbed to the cruel reality. As soon as the death of Mr. Shelby, Mrs. Shelby took over the family's economic power and she decided to buy Tom back immediately. 
Meanwhile, influenced by Mrs. Shelby, her son George Shelby was willing to take action to buy Tom back, though Tom passed away. Ultimately, George liberated all the slaves of their own manor, from this point of view, Mrs. Shelby's rebellion was a success.

Compared with Uncle Tom, Aunt Chloe was brave and filled with rebellious spirit. When knowing that he was to be sold by the master, Tom neither thought of escaping nor made any complaints, on the contrary, Aunt Chloe supported Tom to escape immediately. "Why don't you go, too? Will you wait to be toted down the river, where they kill niggers with hard work and starving? I'd be heap rather die than go there, any day! There's time for ye; be off with Lizzy, you've got a pass to come and go anytime. Come, bustle up, and I'll get your things together." Later, she also bravely pointed that it was wrong for Mr. Shelby to sell Uncle Tom to pay off his debt. After Tom's leaving, Aunt Chloe didn't give up buying Tom back for her awkward economic situation. She would rather separate from her children to raise money by making cakes than sitting still. It could be concluded that Aunt Chloe had very clear self-consciousness and distinguished morals.

Eliza's escape was undoubtedly the most touching scenes in this novel. As soon as she knew that her son would be sold to pay off the debt, she made the decisive choice to flee. In the absence of any ferry, Eliza held her son tightly and jumped into the icy water to escape the arrest without hesitation. She totally forgot the physical pain and only wanted to be free. "With wild cries and desperate energy she leaped to another and still another cake; stumbling-leaping-slipping-springing upwards again! Her shoes are gone-her stockings cut from her feet while blood marked every step; but she saw nothing, felt nothing, till dimly.” Needless to say, as an obedient woman, Eliza's rebellion absolutely originated from the great maternal love. In order to protect her son, she risked her life to step on the floating ice across the Ohio River. Apparently, it was Eliza's supreme maternal love that support her to overcome all kinds of hardships. As a mother, Eliza's resistance and rebellious spirit was far stronger than her husband George.

\section{Conclusion}

Uncle Tom's Cabin is an important anti-slavery novel, but it differs from the general story of the Black slaves. Apart from criticizing the slavery, Mrs. Stowe also depicted female's moral progress, rebellious spirit and maternal love. Her purpose was to arise the sympathy of American women, and appeal them to oppose slavery and save the society. Through the analysis of this novel from the female perspective, it can be inferred that both the Black women Eliza, Aunt Chloe, Cassy, Topsy and the White women Eva and Mrs. Shelby have presented strong self-consciousness which has a profound impact on the society and slavery. Mrs. Shelby's lacking initiative in economy demonstrates that women and men didn't share the equal rights in the mid- $19^{\text {th }}$ century American society. According to the story about of Eliza and Cassy, we can see that most of the Black slaves suffer a lot from slavery. That is to say, there is still a long way to go for the equality between men and women, the Black and the White.

The female consciousness shown in this novel has changed people's stereotyped ideas about women and presented the modern women's new image. Women have the right to pursue freedom and choose their own life rather than submitting to fate.

\section{References}

[1] Anderson, Beatrice A. Uncle Tom: A hero at last [J]. ATQ, 1991(03).

[2] Bloom, Harold. Harriet Beecher Stowe’s Uncle Tom's Cabin [M]. InfoBase Publishing, 2008.

[3] Grant,Reg. Slavery [M]. Dorling Kindersley Limited, 2009.

[4] Rubinstein, Annette T.. American Literature Root and Flower [M]. Foreign Language Teaching and Research Press, 1998.

[5] Stowe, Harriet Beecher. A Key to Uncle Tom's Cabin: Presenting the Original Facts and Documents upon Which the Story is Founded [M]. Books, 1998. 